\title{
Effect of Pricing Methods and Public Paying Fee on Cleaning \& Sanitation Service in Zanzibar: A Case of West B Municipality
}

\author{
Ali Abdallah Natepe ${ }^{1 *} \quad$ Abdalla Ussi Hamad ${ }^{2} \quad$ Saleh Said Mwinyi ${ }^{3}$ \\ 1.MBA Student, Zanzibar University \\ 2.Lecturer, Faculty of Arts and Social Science, Zanzibar University, P.O. Box 2440, Zanzibar \\ 3.Lecturer, Faculty of Business Administration, Zanzibar University, P.O. Box 2440, Zanzibar
}

\begin{abstract}
The main objective of the study was to assess the effect of pricing methods and public paying fee on cleaning and sanitation services in West B Municipality, Zanzibar. The survey questionnaire was distributed to the business owner with sample size of 150 and data were collected and analysed based on both descriptive and inferential statistics through Pearson correlation using SPSS version 23. The study results through descriptive the study shows that about 98 respondents which made $65.3 \%$ replied that there is no impact brought by pricing methods and public paying fee on cleaning and sanitation services. Although the result from person correlation state that there is no significant positive relationship between pricing methods and public paying fee on Cleaning Service \& sanitation services. The study recommends that the municipality should establish a specific model for pricing municipality services including cleaning and sanitation services.
\end{abstract}

Keywords: Pricing Methods, Public Paying Fee and Cleaning and Sanitation Service

DOI: $10.7176 / \mathrm{EJBM} / 12-29-04$

Publication date:October $31^{\text {st }} 2020$

\section{Introduction}

Price sensitivity is the degree to which the price of a product affects consumers purchasing behaviours (Assael and Henry, 2004). In economics, price sensitivity is commonly measured using the price elasticity of demand. Price elasticity of demand is a measure of the relationship between a change in the quantity demanded of a particular good and a change in its price (Sarah et al., 2015).

Sanitation and cleaning services have commonly been provided by state-owned, monolithic water organizations. As part of a general move to market-led systems in the 1980s and 1990s, a new paradigm emerged to transform utilities into more modern service delivery organizations that emphasize operational and financial sustainability (Foret and Procházka, 2007).

In Tanzania, especially Zanzibar, price sensitivity can choose a wide variety of optional pricing plans, including flat rates, pay-per-use tariffs, or two-and three-part tariffs because consumers' tariff choice affects their usages, the billing rate, and the company's revenues (Nesaee, 2009). The best examples are telecommunication, online information. Consumers pay only an access price for a flat-rate tariff, whereas pay-per-use tariffs charge only a usage price (Prameela and Husain, 2007). In a two-part tariff, consumers pay both an access price for having access to the service and a usage price for the quantity used. Consumers get a usage allowance for paying the access price in a three-part tariff, e.g., free minutes on a cell-phone plan, and then pay a usage price only when their usage exceeds the allowance (Sanga, 2007).. It is assumed that consumers prefer the tariff that minimizes their billing rate, given their expected usage when choosing among menus of those tariffs.

\section{Research Problem}

More interesting, in every financial year West B Municipal Council which is formally was West Municipal, adjust the prices of its services by increasing the prices from internal Sources of Revenue to meet its Budgets, but five years statistics have shown that numbers of hold and Business venture who pays Cleaning Service \& sanitation fees voluntarily were decreasing at increasing rate, from 5,780 in 2010 to 3,457 in 2015(Municipal Annual Report2015).

Even though Council increases prices of its services to meet the Budgets, yet it is not benefited from the adoption of this method. West B Municipal Council wants to find out current sources of the problem if it is caused by the Price changes or other factors facing these challenges, several times the Council have been hired teams of Experts for assistance in the strategies for institutional strengthening and capacity building programs that involve undertaking assessment and situation analysis in the council.

However, planning pricing strategy merely to happen is insufficient: ignoring planned strategy following its creation needs to avoid explicitly. Planned pricing strategy must have a significant presence in organizational attention, cognition, and interpretation.

Therefore, the main objective of this paper is to examine the effect of pricing methods and public paying fee on cleaning service \& sanitation in west b municipality in Zanzibar. 


\section{Literature Review}

The infrastructure services concentrated by municipalities are different from the goods and services produced by industrial or business firms; they are not private goods services by nature (Ajam, 2001). In the case of private goods, market acts as an instrument of competition and regulation, and the prices are determined by supply-demand conditions; in efficient and competitive markets, the price of good and service is arrived at from the market clearing operations (Bond, 2000). Based on these prices, the individual firm takes production decisions and how much and when to produced.

The pricing methods enables the civic authorities to provide these services from a demand perspective, the authorities will respond to demand by providing appropriate service with the costs being fully recovered (Botes \& Pelser, 2001). They discipline people at large since policies can be framed in such a manner that they can discourage any wastage of Municipal Infrastructure Services. User charge can also be used as a redistributive mechanism in order to address some of the social/economic issues like concerns of the poor (Centre for Development Support (CDS). 2001).

The pricing policies were not seen as an instrument of redistribution but now user charges can be made nonregressive by using either differential or progressive tariffs or through means testing, with reduced tariffs or exemptions for the old and the poor (Craythorne, 2006). User charge enables allocate efficiency, by fully recovering the operational costs of the municipal infrastructure service, the government or government agency does not consume resources meant for other services or sectors (Fjeldstad \& Semboja, 2001). In essence, the rationale for the levy of user charges is not only to generate revenues but also to promote economic efficiency.

While fixing the user charges, it is also important to examine the feasibility of cost-recovery, which may vary with respect to the type of service, provided (Mabotja, 2002). The extent of cost recovery from civic infrastructure services also depends upon the nature of benefits that accrue from a given service and the extent and nature of the subsidy likely to be available (Moses, 2002). Pricing is an important component of user charge system and tariffs are normally used to the consumers for the services provided. A user charge system needs to adopt an appropriate pricing mechanism after taking into account current practices in the urban local body.

There are instances where a municipality might feel that instead of providing the service directly, it would be better to hire someone else (service provider) to do it (VTPI, 2007). Reasons why a municipality would choose this route include the fact that other municipalities, Nongovernmental Organizations (NGOs) or Community-Based Organizations (CBOs) or private companies might have better resources and management skills to provide the service than the municipality itself (Todd 2007). Whatever method a municipality chooses, it must always be in line with the overall goals of improving the quality of services, extending services to residents who do not have them and providing services at an affordable cost. It is important to provide services that are affordable, but municipalities must do so without compromising on their ability to operate and maintain existing services (Donald, 2004).

\section{Conceptual Framework}

The figure below is used to present the diagrammatic representation of the logical paths of this study. With the aid of the single head arrows, the interconnections among the dependent and independent variable are shown. There is only one dependent variable, cleaning service and sanitation fees and two independent variables, pricing methods and public paying fee. The figure illustrate that how these two independent variables (pricing methods and public paying fee) could led to better performance of cleaning and sanitation services in West B in Zanzibar.

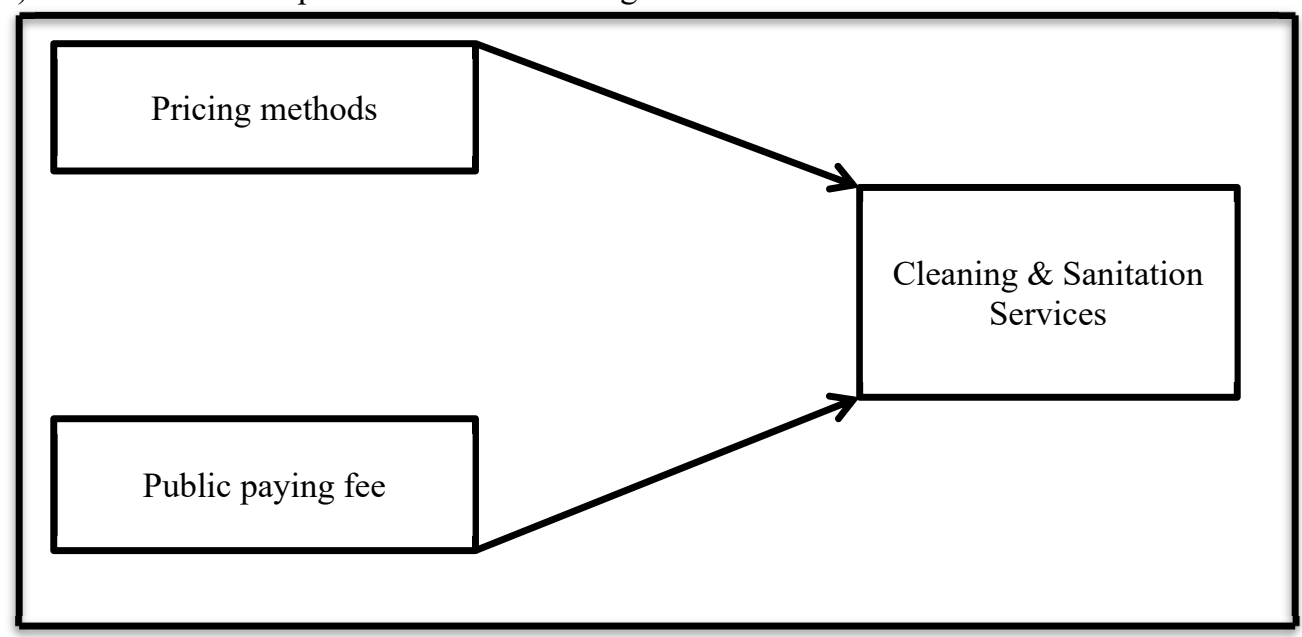

Figure 1: Conceptual Framework 


\section{Research Methodology}

This area shows how the paper conducted in order to capture the information easily. In terms of design, a quantitative research design was used in this study in order to explore a phenomenon, explain and interpret the data widely and easily. The rationale of choosing this research design was to enabled the researcher to solve the issue at hand and to show the magnitude of the pricing methods and public paying fees on cleaning and sanitation services .

The target population was household, business venture, West B Municipal's Staffs and Ministry responsible for LGAs Staffs. The rational of this selection is because there is a huge discussion on pricing methods and paying for municipality Cleaning Service and sanitation fees in this area. Although, the households and business venture are the main victims in paying this services.

A total of 150 respondents were involved to provide information about the study investigation using multistage cluster sampling techniques. Primary data was collected using questionnaire survey from the targeted respondents in order to know the reality of what is happening to them at a point in time is preferred. The questionnaire is developed based on a Likert scale (from 1 to 5) because it includes question which require the respondents to indicate how much or to what extent they agree or disagree with the given statement on each construct

Descriptive statistics such as frequencies mean and standard deviation as well as inferential statistics such as standard and hierarchical linear regressions was used for data analysis. The data were analysed by the assistance of a statistical package of social sciences (SPSS) software version 23.

\section{Result and Discussion}

6.1 Demographic of the Respondents

Characteristics of respondents are very important in a social science research as far as the study use primary data as a source of data collection. To show that significant, the researchers prefer to use the following demographic variables such as, age, gender, education, marital status and occupation of the 150 respondents have been examined and presented below.

Table 1 Demographic of the respondents

\begin{tabular}{|l|l|l|}
\hline Variable & Category & Percentage (\%) \\
\hline Gender & Male & 52.7 \\
& Female & 47.3 \\
\hline \multirow{5}{*}{ Age } & $20-30$ & 15.3 \\
& $31-40$ & 16.7 \\
& $41-50$ & 21.3 \\
& $51-60$ & 32.7 \\
& 61 and above & 14 \\
\hline \multirow{4}{*}{ Marital Status } & Married & 48.7 \\
& Single & 23.3 \\
& Divorced/widow & 28 \\
\hline \multirow{5}{*}{ Education } & Government & 40.7 \\
& Non-government & 59.3 \\
\hline & Degree \& above & 23.5 \\
& Diploma & 20 \\
& Secondary & 5.5 \\
& Primary & 36 \\
& No formal education & 15 \\
\hline
\end{tabular}

From the table 1 above summarises the demographic information about the respondents. The number of male respondents are greater compared to female. This is because, in West B municipality, male are the most business owner and taking care of their family. Although, the age of the respondents in the social research is the one of the most important characteristics in capturing their views about a particular problem (Abideen 2010). The result in the table above it seems to suggest 68 percent of the respondents are the ages of 41 and above, which is more than half of the total respondents. This indicates that most of business man and women are matured and economically active labor force and they can manage well their business and taking the responsibilities to their family.

Furthermore, 48.7 percent of the total respondent were married which is almost half, 28 percent were divorced and only 23.3 percent were single. This implies that the researcher include all kind of marital status so as to avoid the act of discrimination and to have the perception from these status. More impressive, on the area of occupation, 59.3 percent were from non-government or private sector and the remaining were from government sector. This means that the private sector were the main victims of municipality services and that why to get their view were very important. Finally, the level education attainment seems to vary in to different level. Most of the respondent were attained their primary education which represent 36 percent and $23.5 \%, 20 \%, 5.5 \%$ and $15 \%$ attained their 
degree, diploma, secondary and no formal education respectively. Due to the nature of this study it must to have respondent who own business regardless their education background. This aspect helps the research during the data collection to identify the level of education of interviewee in order to choose the best language style.

\subsection{Descriptive Statistics}

The descriptive statistics was conducted in order to determine the people's responses on the pricing methods and public paying fees used by West B Municipality in Zanzibar. The following results below were obtained.

Table 2. Descriptive statistics for pricing methods and public paying fee on cleaning \& sanitation service

\begin{tabular}{|l|l|l|l|l|l|}
\hline \multicolumn{1}{|c|}{ OPTIONS } & $\begin{array}{l}\text { Strongly } \\
\text { agree }\end{array}$ & Agree & Neutral & Disagree & $\begin{array}{l}\text { Strongly } \\
\text { disagree }\end{array}$ \\
\hline $\begin{array}{l}\text { Western B municipality has modern looking } \\
\text { equipment }\end{array}$ & $14.7 \%$ & $5.3 \%$ & $8 \%$ & $24 \%$ & $48 \%$ \\
\hline $\begin{array}{l}\text { Materials associated with the service are clear } \\
\text { and attractive }\end{array}$ & $12.0 \%$ & $15.3 \%$ & $7.3 \%$ & $26.0 \%$ & $39.3 \%$ \\
\hline $\begin{array}{l}\text { The WEST B municipality provides their } \\
\text { services on time }\end{array}$ & $12.0 \%$ & $15.3 \%$ & $7.3 \%$ & $24.7 \%$ & $40.7 \%$ \\
\hline $\begin{array}{l}\text { The services provided by West B municipality } \\
\text { are good and interesting }\end{array}$ & $10.7 \%$ & $18.0 \%$ & $6.0 \%$ & $38.0 \%$ & $27.3 \%$ \\
\hline $\begin{array}{l}\text { The price of services provided by municipality is } \\
\text { reasonable }\end{array}$ & 18.0 & 10.0 & 5.3 & 20.7 & 46.0 \\
\hline $\begin{array}{l}\text { Effective in handling customer's service } \\
\text { problems }\end{array}$ & 10.7 & 18.7 & 6.0 & 24.0 & 40.7 \\
\hline
\end{tabular}

The table 2 above shows how the respondents reactions on the pricing methods and public paying fees used by West B Municipality in Zanzibar. The result indicates that, the equipment used by Municipality to price cleaning services and sanitation is not up to date since more than 50 percent of the respondents disagree with the statement. On the issue of material associated with the services, almost 40 percent of the respondents they are strongly disagree that materials are not good and strong enough for the cleaning services of the Western B Municipality. Regarding to the punctuality, more than 50 percent of the respondents they are against the statement that the municipality provide their services on time. This indicate that people they are not comfortable with the method used by Municipality office.

Much interesting, the services provided by municipality seem are not and not interesting. In this aspects the respondents were much disagree compared to strongly disagree. It means that if the municipality will improve their services automatically the result on this area will be something else. In addition to that, the price charged by Municipality for cleaning and sanitation fees are not reasonable where 69 out of 150 of the respondents represent 46 percent were strongly disagree with the statement. This implies that the office they don't have price base for charging these services. Lastly but not list, the result indicate that the West B Municipality are not able to handle the customer's services problem because more than $50 \%$ of the total respondents were strongly disagree.

\subsection{Inferential Statistics}

Apart from descriptive statistical techniques, the inferential analysis techniques such as standard and hierarchical multiple regressions were used in order to determine the relationship between pricing methods and public paying fee on Cleaning Service \& sanitation in West B Municipality Zanzibar. All assumptions aligned for this technique were meeting and the following result was obtained.

Table 3: Relationship between pricing methods and public paying fee

\begin{tabular}{|c|c|c|c|c|c|c|c|}
\hline \multicolumn{8}{|c|}{ Correlations } \\
\hline & & CBPM & DBPM & COBPM & ME & GSMACS & GS \\
\hline \multirow[t]{3}{*}{ СВРМ } & Pearson Correlation & 1 & $1.000^{* *}$ & $1.000^{* *}$ & -.046 & -.099 & -.046 \\
\hline & Sig. (2-tailed) & & .000 & .000 & .573 & .230 & .573 \\
\hline & $\mathrm{N}$ & 150 & 150 & 150 & 150 & 150 & 150 \\
\hline \multirow[t]{3}{*}{ DBPM } & Pearson Correlation & $1.000^{* *}$ & 1 & $1.000^{* *}$ & -.046 & -.099 & -.046 \\
\hline & Sig. (2-tailed) & .000 & & .000 & .573 & .230 & .573 \\
\hline & $\mathrm{N}$ & 150 & 150 & 150 & 150 & 150 & 150 \\
\hline \multirow[t]{3}{*}{ COBPM } & Pearson Correlation & $1.000^{* *}$ & $1.000^{* *}$ & 1 & -.046 & -.099 & -.046 \\
\hline & Sig. (2-tailed) & .000 & .000 & & .573 & .230 & .573 \\
\hline & $\mathrm{N}$ & 150 & 150 & 150 & 150 & 150 & 150 \\
\hline \multirow[t]{3}{*}{ ME } & Pearson Correlation & -.046 & -.046 & -.046 & 1 & -.019 & $1.000^{* *}$ \\
\hline & Sig. (2-tailed) & .573 & .573 & .573 & & .816 & .000 \\
\hline & $\mathrm{N}$ & 150 & 150 & 150 & 150 & 150 & 150 \\
\hline
\end{tabular}




\begin{tabular}{|c|c|c|c|c|c|c|c|}
\hline \multicolumn{8}{|c|}{ Correlations } \\
\hline & & CBPM & DBPM & COBPM & $\mathrm{ME}$ & GSMACS & GS \\
\hline \multirow[t]{3}{*}{ GSMACS } & Pearson Correlation & -.099 & -.099 & -.099 & -.019 & 1 & -.019 \\
\hline & Sig. (2-tailed) & .230 & .230 & .230 & .816 & & .816 \\
\hline & $\mathrm{N}$ & 150 & 150 & 150 & 150 & 150 & 150 \\
\hline \multirow[t]{3}{*}{ GS } & Pearson Correlation & -.046 & -.046 & -.046 & $1.000^{* *}$ & -.019 & 1 \\
\hline & Sig. (2-tailed) & .573 & .573 & .573 & .000 & .816 & \\
\hline & $\mathrm{N}$ & 150 & 150 & 150 & 150 & 150 & 150 \\
\hline
\end{tabular}

KEY:

$\begin{array}{ll}\text { CBPM } & =\text { Cost }- \text { Based Pricing Methods } \\ \text { DBPM } & =\text { Demand }- \text { Based Pricing Method } \\ \text { COBPM } & =\text { Competition }- \text { Based Pricing Method } \\ \text { ME } & =\text { Modern Equipment } \\ \text { GSMACS } & =\text { Good and Strong Material Associated with Cleaning Services } \\ \text { GS } & =\text { Good Services }\end{array}$

So as to accomplish this objective, correlation was conducted using Pearson's correlation coefficient (r). The results indicate that there is no significant positive relationship between pricing methods and public paying fee on Cleaning Service \& sanitation. According to Sedgwick, and Philip (2012) correlation analysis is basically applied to explain the strength and direction of the linear relationship between two variables. In line with this explanation, correlation analysis was specifically carried out in order to see the strength and direction of the study variables like pricing methods on: modern equipment used, good services provided, good and strong materials used.

Generally, Pearson's correlation coefficients (r) take only values for -1 to +1 in which the sign indicates whether there is a positive correlation - this means that when one variable increases, the other also increases or a negative correlation which means that when one variable increases, the other one decreases, though when the value of zero (0) is obtained, this indicates that two variables do not have any relationship (Schober et al., 2018).

According to Cohen (1988), Person's correlation coefficient is classified into three sizes namely small, medium and large as seen in Table 4.14

Table 4 Interpretation of Person's correlation coefficient (r)

\begin{tabular}{ll}
\hline Values of Pearson's correlation coefficient & Interpretation \\
\hline $\mathrm{r}=0.10$ to 0.29 & Small correlation \\
$\mathrm{r}=0.30$ to 0.49 & Medium correlation \\
$\mathrm{r}=0.50$ to 1.0 & Large correlation \\
\hline
\end{tabular}

Source: Cohen $(1988$, pg $79-82)$

The results of the Pearson's correlation coefficient (r) of the present study show that most of the variables positively not correlated, means they did not show any relationship between them. For example, in looking the strength of the relationship between Cost -Based Pricing Method, Demand Based Pricing Method, and Competition - Based Pricing Method with Modern Equipment used, Good and Strong Materials used and Good services were provided is clearly seen that there is no relationship since all values of correlation coefficient of variables are larger than the critical values $(\mathrm{p}>0.01)$. For example Cost - Based method with modern equipment used (-.046, $\mathrm{p}>0.01)$, Cost -Based Method with materials used to provide services $(.099, \mathrm{p}>0.01)$ and Cost Based Method with general service provided (-.046, $\mathrm{p}>0.01)$. Generally, this is total indicated that the pricing methods and public paying fee used in West B Municipality have no significant effects on the services provided like cleaning services and sanitation services. Therefore there is the need the Authority to establish the best model to be used so as to clear these problems.

This is supported by the study conducted by Ajam, (2001) who he said that the infrastructure services concentrated by municipalities are different from the goods and services produced by industrial or business firms; they are not private goods services by nature. In the case of private goods, market acts as an instrument of competition and regulation, and the prices are determined by supply-demand conditions; in efficient and competitive markets, the price of good and service is arrived at from the market clearing operations. Based on these prices, the individual firm takes production decisions and how much and when to produce on their own

\section{Conclusion}

The study assessed the effect of price methods and public paying on cleaning and sanitation services in West B Municipality, Zanzibar. Most of the respondents agreed that there are the impacts like low quality services, low quality of the equipment services and high paying fee of the services provided. In addition to that after being told to rate the impact more than $50 \%$ of the respondents replied low and very low impact of the services provided. Also about the quality of equipment used by Municipality most of the respondents almost $70 \%$ of the total were 
disagree and said that the equipment's used most of them are old and not modern. About the quality of the materials used by West B Municipality most of the respondents in the field disagree that materials are not good. Most of the respondents also disagree that West B Municipality are not providing services on time as planned by the authority. This is noted that they are not full responsible on providing services like cleaning and sanitation. Even though more than $50 \%$ of the respondents disagree that the services provided by West B Municipality are not good and not interesting to the customers on the organization of the services, West B Municipality are not well organized since most of the respondents were strongly disagree.

\section{Recommendations}

It can be said undoubtedly that some time there are a lot of studies about price sensitivity and Municipality services. But, most of the researches are related with the products not with the impact of the price methods and services sensitivity. It is recommend that Municipality authority should emphasize on the service provided to the consumers such as clearing services, improve the consumers environment for the business, medical or clinical service and sanitation services

Not just only an amount that customers pay for utilizing a product or having a service. Price is most influencing factor for buying a product and for earning profit from selling the product. It is most influencing factor for buying because consumers are rational; they have limited income as well as limited budget therefore Municipality authorities should stick and plan affordable and specific price to the consumers.

\section{References}

Aguinis, H. and Jeffrey R. E. (2014). "Methodological Wishes for the Next Decade and How to Make Wishes Come True." Journal of Management Studies 51 143-174

Fraenkel, J. R., N.E., and Hyun, H. H. (2012). How to design and Evaluate Research in Education (8th ed). Boston: MC Graw- Hill.

Gay, L. R., Mills, G. E., and Airasian, P. W. (2012). Educational Research Competencies for Analysis and Applications. New Jersey; Prentice Hall.

John P.A. (2007)."Limitations are not Properly Acknowledged in the Scientific Literature." Journal of Clinical Epidemiology 60 324-329

James H. and Judy M. (2004) "Research Limitations and the Necessity of Reporting Them." American Journal of Health Education 35 : 66-67;

Kothari, C. R. (2004). Research Methodology: Methods \& Techniques. New Age International (P) Ltd (Second Rev). New Age International Publishers.

Managing Municipal Solid Waste with Unit-Based Pricing: Policy Effects and Responsiveness to Pricing Land Economics November 1, 2011 87: 645-660

Pasek, J. (2012). Writing the Empirical Social Science Research Paper: A Guide for the Perplexed.

Sweeney, Jillian C. and Geoffrey N. S. (2001). Consumer Perceived Value: The Development of a Multiple Item Scale, Journal of Retailing, 77(2), 203-220.

Ajam, T. (2001). Intergovernmental Fiscal Relations in South Africa. The Challenges of Cooperative Government. Cape Town: IDASA/School of Government, University of the Western Cape

Bond, P. (2000). Cities of Gold, Townships of Coal: Essays on South Africa's New Urban Crisis. Trenton, NJ: AfricaWorld Press.

Botes, L.J and Pelser, A.J. (2001). Non-payment of Municipal Services: Base-line Survey Report. Bloemfontein: Centre for Development Support, University of the Free State.

Craythorne, D.L. (2006). Municipal Administration, Handbook 6th Edition. Juta \& Co, Ltd.

Fjeldstad, O. H. \& Semboja, J. (2001). Why People Pay Taxes: The Case of the Development Levy in Tanzania, World Development 29, 12.

Mabotja, S. (2002). People can't Pay Lights Bills: It's not that Households are Unwilling to Pay; they Simply can't Afford the Municipal Bills. Finance Week.

Todd L. (2007), Parking Taxes: Evaluating Options and Impacts, VTPI (www.vtpi.org); at www.vtpi.org/parking_tax.pdf.

Donald S. (2004), "The Ideal Source of Public Revenue," Regional Science and Urban Economics, Vol. 34, pp. 753-784; at http://shoup.bol.ucla.edu/IdealSource.pdf.

Assael, H. (2004), Consumer Behavior: A Strategic Approach, Boston: Houghton Mifflin.

Foret, M., and Procházka, P. (2007).“Buying Behaviour of Households in the Czech Republic".Agricultural Economics - Czech, 53(7), pp 318-324.

Kim, R. (2009). "Factors influencing Chinese consumer behavior when buying innovative food products" Agricultural Economist - Czech, 55, (9), pp 436- 445.

Mugacha, S. (2013).Uchumi Supermarket: And the growth story continues. Faida Investment Bank, Nairobi.

Nesaee, V. (2009).Marketing techniques and principles, Terme Publication, Tehran 
Prameela, V. and Husain, S. (2007). "Consumer choice of branded agro-processed products in Kannur municipality of Kerala state",Journal of Tropical Agriculture, Volume 45 (1-2), pp 72-74

Sanga, D. A. (2007)."Factors influencing consumer brand choice and purchasing decision making process: The case of bottled drinking water Tanzania". MBA Dissertation. University of Dar es Salaam. Tanzania. (Unpublished)

Belás J. \& Gabčová, L. (2016). The relationship among customer satisfaction, Loyalty and financial performance of commercial banks. E \& M Economic and Management, Volume 2, Issue 1, pp 132-144

Renison, K. and Hardt, L. (2008). Price and Revenue Optimization for Banking. In Proceedings of the SAS Global Forum 2008, 1-7, San Antonio, Texas, USA

Santonen, T. (2007). Price Sensitivity as an Indicator of Customer Defection in Retail Banking. International Journal of Bank Marketing, 25(1), 39-55.

Sarah Mmari, John Safari, James Lwelamira (2015). Consumers' Perceptions on Packaging of Processed Food Products in Dodoma Municipality, Tanzania, Social Sciences. Vol. 4, No. 4, 2015, pp. 77-81. doi: 10.11648/j.ss.20150404.11

\section{Biodata of the authors}

Ali Abdallah Natepe, born 1982 in Zanzibar. He promoted to current position as a Director in West B Municipal Council in October 2018, before that he wa appointed as a Deputy Director in Urban Municipal council from November 2016 to October. He graduated in Zanzibar University 2009 with a Bachelor Degree in Business Administration optional Marketing. Also he take some Other short courses in Management and Administration such as Managing Meeting in Public Institution provided by Central for good governance and Economic Development (2015), NAPS- InfoBridge (2013) and Research for Education and Democracy in Tanzania from University of Dar es Salaam (2007). With eleven years of experiences working alongside with the executive teams of Local Government Authorities I use to encourage other to work hard and succeed the goals and objectives.

Abdalla Ussi Hamad born and raised in Zanzibar 1985, till now lives in Zanzibar. He holds a PhD in Islamic Banking and Finance (International Islamic University of Malaysia, 2018), an MSc Finance (International Islamic University of Malaysia, 2013) and Bachelor of Business Administration (BBA) majoring in Accounting and Finance (Zanzibar University, 2010). His academic accomplishments include some articles in professional journals. Dr. Abdalla's research and consulting services concern Islamic banking operations, social finances mechanisms as well as poverty alleviation issues, economics modeling, financial and managerial accounting etc

Saleh S. Mwinyi has been a Lecturer and former Dean of Faculty of Business Administration at Zanzibar University, Tanzania. He received his MBA (Marketing) from Annamalai University and BCom from Rajasthan Vidyapeeth University, India in, respectively, 2001 and 1999. He has more than seventeen years of teaching and professional experience in market analysis and development, international trade and organizational behavior. Currently, he is an entrepreneurship professional mentor for small and medium enterprises in Tanzania, East Africa. $\mathrm{He}$ is in thesis stage of his $\mathrm{PhD}$ programme. 